2. На основі положень механіки контактної взаємодії, зокрема, теорії пружного контакту Герца, встановлено залежності величин діаметра роликів та робочого зусилля стенда від експлуатаційних характеристик колісної пари, до складу якої входить випробовуване колесо. Доведено взаємний вплив цих величин.

3. Встановлено функціональну залежність, яка пов'язує між собою тривалість випробувань, частоту обертання випробовуваного колеса та кількість роликів; вона також визначає вплив характеристик колісної пари на ці величини.

\title{
Література:
}

1. Воробьев А. А. Прогнозирование ресурса и совершенствование технологии ремонта колес железнодорожного подвижного состава: автореферат дис. ... доктора техн. наук, 05.22.07 - подвижной состав железных дорог, тяга поездов и электрификация. 2018. 36 с.

2. Джонсон К. Механика контактного взаимодействия: пер. с англ. Москва, 1989. 510 с.

DOI https://doi.org/10.30525/978-9934-588-79-2-2.43

\section{ДОЦІЛЬНІСТЬ ВИКОРИСТАННЯ ДИЗЕЛЬНОГО БІОПАЛИВА МІСЬКИМИ АВТОБУСАМИ}

\author{
Сімоненко В. В. \\ кандидат технічних наук, \\ дочент кафедри дорожніх машин \\ Національного транспортного університету \\ м. Київ, Украӥна
}

В теперішній час основна частина моторних палив виготовляється 3 корисних копалин, в основному, з нафти. Серед різних видів транспорту іiі частка особливо велика в автотранспорті, на потреби якого витрачається більше $50 \%$ від загальної кількості видобутої сировини. Серед усіх видів наземного та водного транспорту близько $64 \%$ моторних палив, що витрачаються, припадає на легкові та вантажні автомобілі, а також автобуси (до 18\%) [1].

Особливе місце серед двигунів внутрішнього згоряння (ДВ3) посідають дизелі, які встановлюються на переважній більшості сільськогосподарських, дорожньо-будівельних машин. Найближчим часом вони збережуть широке використання на автомобільному транспорті, 
що зумовлює актуальність досліджень, проведених в Національному транспортному університеті (м. Київ, Україна) та присвячених проблемі використання в дизелі альтернативних палив (АП).

Необхідність використання АП викликана двома глобальними проблемами: світовим дефіцитом нафти та забрудненням довкілля [2].

Інтенсивне вичерпання викопних джерел енергії тягне за собою загострення міжнародних конфліктів. В той же час викиди шкідливих речовин (ШР) з відпрацьованими газами (ВГ) ДВЗ негативно впливають на організм людини, а також на навколишнє середовище в цілому. Тому заміна традиційних нафтових палив альтернативними джерелами енергії може значно зменшити теплове забруднення атмосфери внаслідок «парникового» ефекту, знизити кількість кислотних дощів, фотохімічний смог тощо.

Обмежені сировинні енергетичні ресурси та високий рівень забруднення довкілля потребує пошуку нових альтернативних джерел енергії. Частковою заміною паливам нафтового походження можуть бути палива з відновлюваної сировини.

Сучасні технології виготовлення дизельного біопалива забезпечують фізико-хімічні властивості, близькі до властивостей традиційного дизельного палива, що дозволяє його використання без внесення змін в конструкцію дизелів.

Враховуючи сприятливі аграрні умови в Україні та особливості процесу виробництва дизельного біопалива доцільно виготовляти та використовувати паливо на основі ріпакової олії (дизельне біопаливо).

Моторні дослідження дизеля 4Ч11,0/12,5 (Д-241), проведені в Національному транспортному університеті [3], підтверджують зміну показників паливної економічності та токсичності дизеля при використанні біопалива. В різних режимах роботи дизеля спостерігалось зростання годинної витрати дизельного біопалива на $11 \ldots 16 \%$. Концентрації $C O$ та $C_{\mathrm{m}} H_{\mathrm{n}}$ при малих навантаженнях двигуна підвищувались, в порівнянні з роботою на дизельному паливі, але зі зростанням навантаження були нижчими на $3 \%$ та $23 \%$ відповідно. Концентрації $N O_{x}$ у ВГ при цьому дещо підвищуються (до 7...9\%). Димність ВГ знижувалась до $35 . .42 \%$ при роботі на дизельному біопаливі.

За результатами моторних досліджень одержано поліноміальні залежності, які: описують двигун як споживач палива, повітря та джерело шкідливих викидів; дозволяють розрахувати витрату палива, повітря та викиди ШР з ВГ дизеля в усьому спектрі швидкісних та навантажувальних режимів при використанні традиційного дизельного палива та дизельного біопалива.

Адекватність поліноміальних моделей підтверджено за допомогою коефіцієнта кореляції та $F$-критерію Фішера. 
Оскільки проблема забруднення навколишнього середовища дуже гостро стоїть у великих містах, були проведені розрахунки на уточненій математичній моделі [4] руху міського автобуса, що працює як на традиційному дизельному паливі, так і на дизельному біопаливі в умовах міського їздового циклу [5].

За результатами розрахунків на математичній моделі руху автобуса в умовах міського їздового циклу встановлено, що при роботі на дизельному біопаливі масова витрата палива за цикл зростає на $11,45 \%$ при русі автобуса без пасажирів і на $14,34 \%$ - при повному завантаженні. Однак, в перерахунку в тепловому еквіваленті витрата дизельного біопалива практично не змінюється, в порівнянні з традиційним дизельним паливом.

Результати розрахунків на математичній моделі засвідчили зниження сумарних масових викидів шкідливих речовин з відпрацьованими газами за цикл при використанні дизельного біопалива на 2,63\%. Сумарні масові викиди токсичних речовин з відпрацьованими газами, приведені до викидів $C O$, знижуються від $3 \%$ до $7 \%$.

Адекватність уточненої математичної моделі підтверджено шляхом порівняння результатів розрахункових досліджень з результатами дорожніх випробувань автобуса ПАЗ-32054 при русі в режимах міського їздового циклу [6]. Розбіжність результатів дорожніх випробувань та розрахункових досліджень на математичній моделі по витраті палива складає $4,56 \%$ для традиційного дизельного палива та $3,47 \%$ для дизельного біопалива.

Наведені результати підтверджують можливість да доцільність повної або часткової заміни традиційних палив нафтового походження для міських автобусів паливом з відновлюваної сировини, особливо в умовах енергетичної залежності України від країн-постачальників нафтопродуктів.

\section{Література:}

1. Девянин С.Н., Марков В.А., Семенов В.Г. Растительные масла и топлива на их основе для дизельных двигателей. Х. : Новое слово, 2007. $452 \mathrm{c}$.

2. Ковбасенко С.В., Сімоненко В.В. Шляхи покращення показників двигунів дорожньо-транспортних засобів. 63 науково-практична конференція науково-педагогічних працівників, аспірантів, студентів та структурних підрозділів університету. К.: НТУ, 2007. С. 17-18.

3. Ковбасенко С.В., Сімоненко В.В. Моторні дослідження показників дизеля при роботі на дизельному біопаливі. Вісник національного транспортного університету. К: НТУ, 2015. Випуск 1 (31). С. 255-262. 
4. Гутаревич Ю., Ковбасенко С., Сімоненко В. Математична модель руху автобуса 3 дизелем в режимах міського їздового циклу при роботі на традиційному та біодизельних паливах. Systemy $i$ środki transportu samochodowego. Wybrane zagadnienia . Seria: Transport. Rzesżow: Politechnika Ryesyowska im. Ignacego Łukasiewicza, 2013. C. 231-238.

5. ГОСТ 20306-90. Автотранспортные средства. Топливная экономичность. Методы испытаний: М.: Изд - во стандартов, 1991. 34 с.

6. Ковбасенко С.В., Сімоненко В.В. Дорожні випробування автобуса, що працює на традиційному нафтовому паливі та дизельному біопаливі. Відновлювальна енергетика. К: IBE НАН України, 2015. № 1 (40). C. $80-86$.

DOI https://doi.org/10.30525/978-9934-588-79-2-2.44

\title{
МЕТОД РОЗРАХУНКУ ГІДРОДИНАМІКИ ВІДКРИТОГО ГРЕБНОГО ГВИНТА У СКЛАДІ РУШІЙНО-РУЛЬОВОГО КОМПЛЕКСУ АZIPOD
}

\author{
Черніков П. С. \\ кандидат технічних наук, \\ доиент кафедри експлуатаиії суднового електрообладнання \\ $i$ засобів автоматики \\ Одеського начіонального морського університету \\ Яровенко В. О. \\ доктор технічних наук, професор, \\ завідувач кафедри експлуатації суднового електрообладнання \\ $i$ засобів автоматики \\ Одеського начіонального морського університету \\ Дрожжин О. Л. \\ кандидат технічних наук, \\ дочент кафедри експлуатація флоту \\ і технологія морських перевезень \\ Одеського начіонального морського університету \\ м. Одеса, Україна
}

Одною з основних якостей, що зумовили причину високого інтересу до сучасних систем електроруху - висока маневреність суден, обладнаних гребними електричними установками (ГЕУ). Для широкого класу суден маневри $є$ одними 3 основних режимів роботи. 180 